\title{
Negative Change in Sex Ratio: A Burning Issue in Ahmednagar District (Maharashtra)
}

\author{
Sandip Sasane ${ }^{1}$, Swati Wabale ${ }^{2}$ \\ ${ }^{1}$ Assistant Professor, Department of Geography, R. B. N. B. College, Shrirampur \\ ${ }^{2}$ B.Ed. Student, S.S. B. College of B. Ed. Shrirampur
}

\begin{abstract}
Declining Sex Ratio is one of the burning issues not only Ahmednagar District but also many districts of India. This issue putting adverse impact on society therefore in present study attempted has been made to statistically analysis of sex ratio of Ahmednagar District during 1951 to 2011 for understanding changing pattern of sex ratio. The results are shocking all 14 tehsils of district had recorded negative sex ratio but Sangamner, Newasa, Pathardi and Karjat tehsils were recorded high negative change during 1951 to 2011. There is urgent need to change the pattern of sex ratio with putting some steps like to take strong action against the illegal ultrasound centres, strictly implementation of the Anti- Dowry Act, to improve the girl child chances of survival with providing nutritional food and empowerment of women.
\end{abstract}

Keywords: Sex Ratio, Negative Change, Burning Issue, Anti- Dowry Act, Girl child

\section{Introduction}

Today India is emerge as fastest growing economy in the world but the evidences shows that the declining Sex Ratio is one of the burning social problem, usually refers as the number of females per thousand males populations not only in backward states but also in developed and urbanized states like Maharashtra. According to census 2011, only 940 females per 1000 males at national level while Maharashtra recorded 925 females per 1000 males, which is below national average. But there is large fluctuation at district level, the highest sex ratio was recorded in Sinddudurgh (1037), Ratanagiri (1123), Gondia (996) etc. while the lowest was recorded in Mumbai city (838), Mumbai Suburban (858), Thane (880) etc. Although there are several laws on female foeticide and schemes to encourage the families to have a girl child, the sex ratio in India has gone down. It clearly point out that people are still prefers son not only in rural areas but also in urban and highly educated areas like Mumbai, Thane, Pune etc. It has been also observed that the trend of sex determination and sex selective abortion is increasing rapidly not only in cities and towns but also in rural areas with the availability of better road and transport facilities (Babita Sinha, P.N. Mari Bhat and S.C. Gulati (2005). Thus it is necessary to take strong action against the illegal ultrasound centres for check on sex selective abortion. Dowry system is also one of the key causes of negative sex ratio hence there is need to strictly implement the Anti- Dowry Act against people demanding and also providing dowry. Sex ratio may be varies Spatiotemporally, age group depending on age specific mortality and sex specific migration. Therefore present study has been focus on tehsil wise investigation for understanding pattern of sex ratio and negative change and cause of negative change in Ahmednagar district.

\section{Study Area}

Ahmednagar district is the largest district of Maharashtra state with geographical area of $17418 \mathrm{sq}$. km. which is 5.66 Per Cent of total area of the State. It lies between $18^{\circ} 2^{\prime} \mathrm{N}$ to $19^{\circ} 9^{\prime} \mathrm{N}$ latitude and $73^{\circ} 9^{\prime} \mathrm{E}$ to $75^{\circ} 5^{\prime} \mathrm{E}$ longitude with covering 14 tehsils. The climate of the region is characterized by hot summers and general dry throughout the year except during the southwest monsoon season. The mean maximum temperature is $39.1^{\circ} \mathrm{C}$ and the mean minimum temperature is $12.3^{\circ} \mathrm{C}$. The average annual rainfall in the district is $568.7 \mathrm{~mm}$. about 77 Per Cent of the annual rainfall in the district is received during the $\mathrm{SW}$ monsoon season (June-September). The population of district is 45, 43,083 (Provisional Census, 2011) out this 573698 (12.62 $\%)$ is belong to Scheduled Castes including 291521 male and 282177 female population. According to the Census Hand Book sex ratio was 971 in 1951, 962 in 1961, 955 in 1971, 959 in 1981, 949 in 1991, 940 in 2001 and 939 in 2011. It shows that overall change of sex ratio is negative.

\section{Methodology}

For the present study tahsil has selected as a basic unit of micro level investigation. The period selected for the present study is during 1951- 2011. The present study is entirely based on secondary data which is collected from the Census Handbook of Ahmednagar 1951 to 2011. Sex Ratio was computed by using following formula through MS Excel.

Where,

$$
\text { Sex Ratio }=\frac{P f}{P m} \times 1000
$$

Pf = Population of Female

$\mathrm{Pm}=$ Population of Male

Lastly, on the base of finding, decades with negative changes were find out and maps were prepared using ArcGIS 9 software

\section{Results and Discussions}

Data regarding sex ratio of each tehsil were collected from census handbook of Ahmednagar district during 1951 to 2011. Sex ratio was calculated with applying formula and absolute change and change in percentage was calculated, changing pattern of sex ratio in district during 1951 to 2011 was presented. (Table1). 


\section{International Journal of Science and Research (IJSR) \\ ISSN (Online): 2319-7064}

Index Copernicus Value (2013): 6.14 | Impact Factor (2015): 6.391

Table 1: Changing Pattern of Sex Ratio in Ahmednagar District during 1951 to 2011

\begin{tabular}{|c|c|c|c|c|c|c|c|c|c|}
\hline $\begin{array}{l}\text { Sr. } \\
\text { No. }\end{array}$ & Tehsil & $\begin{array}{c}\text { Sex Ratio } \\
1951\end{array}$ & \begin{tabular}{|c|} 
Sex Ratio \\
1961 \\
\end{tabular} & $\begin{array}{c}\text { Absolute } \\
\text { Change }\end{array}$ & $\begin{array}{l}\text { Change in } \\
\text { percentage }\end{array}$ & $\begin{array}{c}\text { Sex Ratio } \\
1961\end{array}$ & $\begin{array}{c}\text { Sex Ratio } \\
1971\end{array}$ & $\begin{array}{c}\text { Absolute } \\
\text { Change }\end{array}$ & $\begin{array}{l}\text { Change in } \\
\text { percentage }\end{array}$ \\
\hline 1 & Nagar & 973 & 935 & -38 & -3.91 & 935 & 901 & -34 & -3.64 \\
\hline 2 & Rahuri & 977 & 953 & -24 & -2.46 & 953 & 952 & -1 & -0.10 \\
\hline 3 & Shrirampur & 947 & 929 & -18 & -1.90 & 929 & 929 & 0 & 0.00 \\
\hline 4 & Newasa & 985 & 973 & -12 & -1.22 & 973 & 975 & 2 & 0.21 \\
\hline 5 & Shevgaon & 997 & 976 & -21 & -2.11 & 976 & 974 & -2 & -0.20 \\
\hline 6 & Pathardi & 983 & 973 & -10 & -1.02 & 973 & 967 & -6 & -0.62 \\
\hline 7 & Jamkhed & 974 & 963 & -11 & $\begin{array}{l}-1.13 \\
\end{array}$ & 963 & 976 & 13 & 1.35 \\
\hline 8 & Karjat & 956 & 950 & -6 & $\begin{array}{l}-0.63 \\
\end{array}$ & 950 & 946 & -4 & -0.42 \\
\hline 9 & Shrigonda & 955 & 945 & -10 & -1.05 & 945 & 949 & 4 & 0.42 \\
\hline 10 & Parner & 1016 & 1008 & -8 & -0.79 & 1008 & 1025 & 17 & 1.69 \\
\hline 11 & Akole & 1007 & 1020 & 13 & 1.29 & 1020 & 959 & -61 & -5.98 \\
\hline 12 & Sangamner & 987 & 987 & 0 & 0.00 & 987 & 974 & -13 & -1.32 \\
\hline 13 & Kopargaon & 956 & 943 & -13 & -1.36 & 943 & 943 & 0 & 0.00 \\
\hline $\begin{array}{l}\text { Sr. } \\
\text { No. }\end{array}$ & Tehsil & $\begin{array}{c}\text { Sex Ratio } \\
1971 \\
\end{array}$ & \begin{tabular}{|c|} 
Sex Ratio \\
1981 \\
\end{tabular} & $\begin{array}{c}\text { Absolute } \\
\text { Change }\end{array}$ & $\begin{array}{l}\text { Change in } \\
\text { percentage }\end{array}$ & $\begin{array}{c}\text { Sex Ratio } \\
1981 \\
\end{array}$ & $\begin{array}{c}\text { Sex Ratio } \\
1991 \\
\end{array}$ & $\begin{array}{l}\text { Absolute } \\
\text { Change }\end{array}$ & $\begin{array}{l}\text { Change in } \\
\text { percentage }\end{array}$ \\
\hline 1 & Nagar & 901 & 894 & -7 & -0.78 & 894 & 912 & 18 & 2.01 \\
\hline 2 & Rahuri & 952 & 952 & 0 & 0.00 & 952 & 943 & -9 & -0.95 \\
\hline 3 & Shrirampur & 929 & 943 & 14 & 1.51 & 943 & 941 & -2 & -0.21 \\
\hline 4 & Newasa & 975 & 953 & -22 & -2.26 & 953 & 945 & -8 & -0.84 \\
\hline 5 & Shevgaon & 974 & 984 & 10 & 1.03 & 984 & 954 & -30 & -3.05 \\
\hline 6 & Pathardi & 967 & 994 & 27 & 2.79 & 994 & 957 & -37 & -3.72 \\
\hline 7 & Jamkhed & 976 & 981 & 5 & 0.51 & 981 & 955 & -26 & -2.65 \\
\hline 8 & Karjat & 946 & 953 & 7 & 0.74 & 953 & 939 & -14 & -1.47 \\
\hline 9 & Shrigonda & 949 & 958 & 9 & 0.95 & 958 & 949 & -9 & -0.94 \\
\hline 10 & Parner & 1025 & 1042 & 17 & 1.66 & 1042 & 1017 & -25 & -2.40 \\
\hline 11 & Akole & 959 & 1007 & 48 & 5.01 & 1007 & 996 & -11 & -1.09 \\
\hline 12 & Sangamner & 974 & 973 & -1 & -0.10 & 973 & 953 & -20 & -2.06 \\
\hline 13 & Kopargaon & 943 & 945 & 2 & 0.21 & 945 & 939 & -6 & -0.63 \\
\hline $\begin{array}{l}\text { Sr. } \\
\text { No. }\end{array}$ & Tehsil & $\begin{array}{c}\text { Sex Ratio } \\
1991\end{array}$ & $\begin{array}{c}\text { Sex Ratio } \\
2001\end{array}$ & $\begin{array}{c}\text { Absolute } \\
\text { Change }\end{array}$ & $\begin{array}{l}\text { Change in } \\
\text { percentage }\end{array}$ & $\begin{array}{c}\text { Sex Ratio } \\
2001\end{array}$ & $\begin{array}{c}\text { Sex Ratio } \\
2011\end{array}$ & $\begin{array}{l}\text { Absolute } \\
\text { Change }\end{array}$ & $\begin{array}{l}\text { Change in } \\
\text { percentage }\end{array}$ \\
\hline 1 & Nagar & 912 & 901 & -11 & -1.21 & 901 & 931 & 30 & 3.33 \\
\hline 2 & Rahuri & 943 & 934 & -9 & -0.95 & 934 & 934 & 0 & 0.00 \\
\hline 3 & Shrirampur & 941 & 949 & 8 & 0.85 & 949 & 962 & 13 & 1.37 \\
\hline 4 & Newasa & 945 & 937 & -8 & -0.85 & 937 & 934 & -3 & -0.32 \\
\hline 5 & Shevgaon & 954 & 953 & -1 & -0.10 & 953 & 953 & 0 & 0.00 \\
\hline 6 & Pathardi & 957 & 951 & -6 & -0.63 & 951 & 926 & -25 & -2.63 \\
\hline 7 & Jamkhed & 955 & 949 & -6 & -0.63 & 949 & 920 & -29 & -3.06 \\
\hline 8 & Karjat & 939 & 933 & -6 & -0.64 & 933 & 914 & -19 & -2.04 \\
\hline 9 & Shrigonda & 949 & 939 & -10 & -1.05 & 939 & 923 & -16 & -1.70 \\
\hline 10 & Parner & 1017 & 988 & -29 & -2.85 & 988 & 955 & -33 & -3.34 \\
\hline 11 & Akole & 996 & 974 & -22 & -2.21 & 974 & 974 & 0 & 0.00 \\
\hline 12 & Sangamner & 953 & 945 & -8 & -0.84 & 945 & 943 & -2 & -0.21 \\
\hline 13 & Kopargaon & 939 & 929 & -10 & -1.06 & 929 & 942 & 13 & 1.40 \\
\hline 14 & Rahata & - & - & - & - & 938 & 940 & 2 & 0.21 \\
\hline
\end{tabular}

(Source: Computed by Researcher)

Table 2: Negative Change in Sex Ratio in Ahmednagar District during 1951 to 2011

\begin{tabular}{|c|c|c|c|c|c|c|c|c|c|}
\hline \multirow{2}{*}{$\begin{array}{l}\text { Sr. } \\
\text { No. }\end{array}$} & \multirow{2}{*}{ Tehsil } & \multicolumn{6}{|c|}{ Sex Ratio Change in percentage (1951 to 2011) } & \multirow{2}{*}{$\begin{array}{c}\text { Decade with } \\
\text { Negative Change }\end{array}$} & \multirow{2}{*}{$\%$} \\
\hline & & 1951-61 & 1961-71 & 1971-81 & 1981-91 & 1991-01 & 2001-11 & & \\
\hline 1 & Nagar & -3.91 & -3.64 & -0.78 & 2.01 & -1.21 & 3.33 & $04(06)$ & 66.66 \\
\hline 2 & Rahuri & -2.46 & -0.10 & 0.00 & -0.95 & -0.95 & 0.00 & $04(06)$ & 66.66 \\
\hline 3 & Shrirampur & -1.90 & 0.00 & 1.51 & -0.21 & 0.85 & 1.37 & $02(06)$ & 33.33 \\
\hline 4 & Newasa & -1.22 & 0.21 & -2.26 & -0.84 & -0.85 & -0.32 & $05(06)$ & 83.33 \\
\hline 5 & Shevgaon & -2.11 & -0.20 & 1.03 & -3.05 & -0.10 & 0.00 & $04(06)$ & 66.66 \\
\hline 6 & Pathardi & -1.02 & -0.62 & 2.79 & -3.72 & -0.63 & -2.63 & $05(06)$ & 83.33 \\
\hline 7 & Jamkhed & -1.13 & 1.35 & 0.51 & -2.65 & -0.63 & -3.06 & $04(06)$ & 66.66 \\
\hline 8 & Karjat & -0.63 & -0.42 & 0.74 & -1.47 & -0.64 & -2.04 & $05(06)$ & 83.33 \\
\hline 9 & Shrigonda & -1.05 & 0.42 & 0.95 & -0.94 & -1.05 & -1.70 & $04(06)$ & 66.66 \\
\hline 10 & Parner & -0.79 & 1.69 & 1.66 & -2.40 & -2.85 & -3.34 & $04(06)$ & 66.66 \\
\hline 11 & Akole & 1.29 & -5.98 & 5.01 & -1.09 & -2.21 & 0.00 & $03(06)$ & 50.00 \\
\hline 12 & Sangamner & 0.00 & -1.32 & -0.10 & -2.06 & -0.84 & -0.21 & $05(06)$ & 83.33 \\
\hline 13 & Kopargaon & -1.36 & 0.00 & 0.21 & -0.63 & -1.06 & 1.40 & $03(06)$ & 50.00 \\
\hline 14 & Rahata & NA & NA & NA & NA & NA & 0.21 & $00(01)$ & 00 \\
\hline
\end{tabular}

(Source: Computed by Researcher)

Volume 5 Issue 6, June 2016 www.ijsr.net

Licensed Under Creative Commons Attribution CC BY 


\section{International Journal of Science and Research (IJSR) \\ ISSN (Online): 2319-7064 \\ Index Copernicus Value (2013): 6.14 | Impact Factor (2015): 6.391}

The negative change in sex ratio in Ahmednagar district during 1951 to 2011 was calculated. Decades with negative change divided by total decades (6) for calculated percentage of negative change (Table 2 ).

\section{Change in 1951 to 1961}

It is observed that 11 tehsils was recorded Negative Sex Ratio, are Nagar (935), Rahuri (953), Shrirampur (929), Newasa (973), Shevgaon (976), Pathardi (973), Jamkhed (963), Karjat (950), Shrigonda (945), Parner (1008), and Kopargaon (943) whereas only Akole (1020) and in Sangamner tehsils were recorded Positive Sex Ratio.

\section{Change in 1961 to 1971}

In this decade picture was changed, 7 tehsils was recorded Negative Sex Ratio and the most striking tehsils were, Nagar (901), Rahuri (952), Shevgaon (974), Pathardi (967), Karjat (946), Akole (953) and in Sangamner (974) while the Positive Sex Ratio were recorded in Newasa (975), Jamkhed (976), Shrigonda (949) and Parner (1025) tehsils. Shrirampur (929) and Kopargaon (943) tehsils were recorded constant sex ratio.

\section{Change in 1971 to 1981}

Tremendous change was occurred in this decade, only 3 tehsils were recorded Negative Sex Ratio and the most striking tehsils were Nagar (894), Newasa (953) and Sangamner (973). Positive Sex Ratio was recorded in 10 tehsils which were Rahuri (952), Shrirampur (943), Shevgaon (984), Pathardi (994), Jamkhed (981), Karjat (953), Shrigonda (958), Parner (1042), Akole (1007), and Kopergaon (945).

\section{Change in 1981 to 1991}

It is observed that 12tahsils were recorded Negative Sex Ratio including Rahuri (943), Shrirampur (941), Nevasa (945), Shevgaon (954), Pathardi (957),Jamkhed (955), Karjat (939), Shrigonda (949), Parner (1017), Akole (996), Sangamner (953), Kopargaon (939). Only Nagar (912) tehsil was recorded Positive Sex Ratio.

\section{Change in 1991 to 2001}

Negative Sex Ratio was recorded in 12 tehsils the most striking tehsils were Nagar (901), Rahuri (934), Newasa (937), Shevgaon (953), Patardi (951), Jamkhed (949), Karjat (933), Shrigonda (939), Parner (988), Akole (974), Sangamner (945) and Kopargaon (929). The Positive Sex Ratio was recorded in Shrirampur (949) tehsil.

\section{Change in 2001 to 2011}

In this decade Newasa (934), Pathardi (926), Jamkhed (920), Karjat (914),Shrigonda (923), Parner (955) and Sangamner(943) were recorded Negative Sex Ratio whereas Positive Sex Ratio was recorded in Nagar (931), Shrirampur (962), Kopargaon (942) and Rahata (940). The constant Sex Ratio was recorded in Rahuri (934), Akole (974) and Shevgaon (953).

\section{Negative Change during 1951 to 2011}

Negative Sex Ratio is one of the burning issues in India; it is observed that sex ratio pattern is not constant during 1951 to 2011 period in district. Most of the tehsils were recorded Negative Sex Ratio but high change was recorded in
Sangamner, 5 decades had negative change and only 1decade (1951 to 1961) recorded constant change. Newasa tehsil also recorded negative change in 5 decades only 1decade (1961 to 1971) recorded positive change. Pathardi tehsil was also recorded negative change in 5 decades only 1decade (1971 to 1981) recorded positive change. Karjat was also recorded negative change in 5 decades only 1 decade (1971 to 1981) recorded positive change. All these four tehsils indicates that 83.33 percentage negative change in sex ratio. Remaining tehsils Kopargaon, Akole, Shrirampur, Shevgaon, Rahuri, Parner, Nagar, Shrigonda and Jamkhed are also shows negative change between 33 to 66 percentages (Fig.1). It is a wakeup call to all of these four tehsils of district; it is time to put urgent steps for positive change in sex ratio in not only in these tehsils but also in entire district.

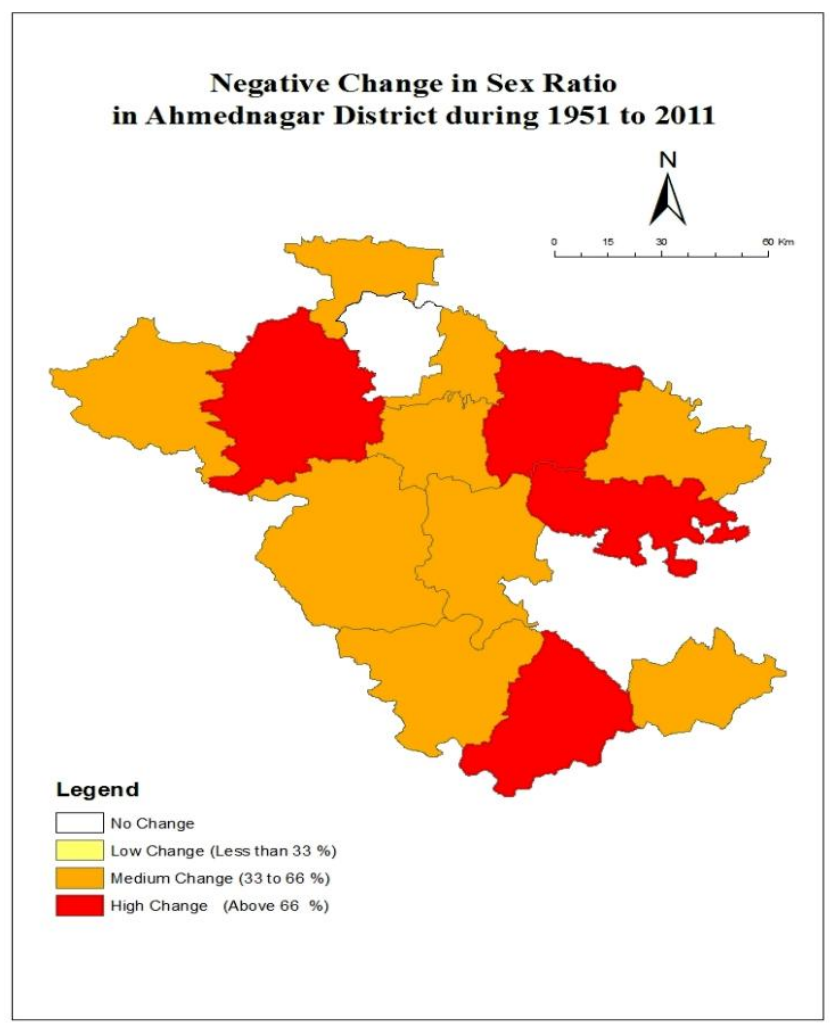

Figure 1: Negative Change in Sex Ratio in Ahmednagar District during 1951 to 2011

\section{Conclusion}

Negative change in Sex Ratio is the one of the foremost challenge for the society; present attempt has been focus on this burning issue in Ahmednagar district. The results are shocking all 14 tehsils of district had recorded negative sex ratio but Sangamner, Newasa, Pathardi and Karjat tehsils were recorded high negative change during 1951 to 2011. There are several causes of negative change in sex ratio; strong son preference is one of the main causes, sexes selective abortion, Dowry system is still one of the major causes of declining female number, poverty, illiteracy, low women status in society etc.

It is time to take strong action against the illegal ultrasound centres for check on sexes selective abortion, the AntiDowry Act should be strictly implemented against people

\section{Volume 5 Issue 6, June 2016 www.ijsr.net}




\section{International Journal of Science and Research (IJSR) \\ ISSN (Online): 2319-7064}

Index Copernicus Value (2013): 6.14 | Impact Factor (2015): 6.391

demanding and also providing dowry, it is necessary for improve the girl child chances of survival with providing nutritional food and better health care within the household, through employment opportunities, empowerment of women should be done for uplifting socio-economic status of women.

\section{References}

[1] Asha Bhende and Tara Kanitkar (2011): Population Studies, Himalaya publishing house, Bombay. Pp.139154.

[2] Barakade AJ. (2012): Declining Sex Ratio an analysis with special reference to Maharashtra, Geoscience research. 2012; 3(1):92-95.

[3] Census Handbook of Ahmednagar District, 1951 to 2011

[4] Cholake \& Sasane (2014): "Declining Child Sex Ratio in Shrirampur tahsil" Proceeding of National Conference on Status of Women in Emerging Social Structure. PP.164-172

[5] Gulati, S. C. (1975)" Component Analysis of the Change in the Sex Ratio: 1951-1961" Demography India, Vol. 4, No. 2, (1975) pp 289-304

Volume 5 Issue 6, June 2016 www.ijsr.net 